\title{
Total organic carbon and its environmental significance for the surface sediments in groundwater recharged lakes from the Badain Jaran Desert, northwest China
}

\author{
Shipei DONG, Zhuolun LI, ${ }^{*}$ Qiujie CHEN, Zhiqiao WEI \\ College of Earth and Environmental Sciences, Center for Desert and Arid Region Research, Lanzhou University, Lanzhou 730000, China \\ *Corresponding author: lizhuolunlzl@163.com
}

\begin{abstract}
Total organic carbon (TOC) content in lake sediments is typically used for the reconstruction of paleoenvironments. It remains uncertain, however, whether these sediment variables in lakes supplied by groundwater in the hinterland of the Badain Jaran Desert are applicable. Moreover, it is still uncertain whether the TOC content in these lakes can be used as a proxy to identify past climatic change and environmental evolution studies. In this study, the spatial distributions of the TOC contents and C/N ratios were analyzed for 109 surface sediment samples collected from five lakes without runoff recharge. The results revealed that the TOC content of the lake surface sediments was extremely low $(0.03 \%-1.01 \%)$ and consisted of both allochthonous organic matter carried by wind, as well as autochthonous organic matter generated in the lakes. Within a lake, spatial differences in the amount of TOC found in surface sediments may be caused by several processes including bathymetry topography and wind-induced wave activity. In addition, wind-induced wave activity produces a higher TOC content, which is more pronounced in larger lakes $\left(>0.21 \mathrm{~km}^{2}\right)$ with longer fetches. By contrast, in smaller lakes, organic matter accumulates in the deeper waters, but can be affected by many factors. It is therefore necessary to consider lake area when applying the TOC content of lake sediments for the reconstruction of a paleolake evolution. Furthermore, because the TOC content of lake sediments in hyper-arid regions is extremely low, and the organic matter may have multiple and varied sources, a single proxy (TOC) cannot be used to reconstruct lake evolution.
\end{abstract}

Key words: Lake evolution; total organic carbon; paleoenviroment reconstruction; Badain Jaran Desert; arid region.

Received: May 2017. Accepted: October 2017.

\section{INTRODUCTION}

Lake sediments in arid and semiarid regions have been widely used to reconstruct regional and global climate changes (Members, 1988; Zhang et al., 2004; Chen et al., 2008; Liu et al., 2016; Hobbs et al., 2017). Total organic carbon (TOC) content in lake sediments is one of the proxies used for the analysis of lake basin ecological environments (Mackay et al., 2012), including the effective humidity (An et al., 1993; Long et al., 2010; Li et al., 2016b), precipitation (Xu et al., 2006; An et al., 2012), runoff (Hartmann and Wünnemann, 2009), and has been widely used in paleoenvironmental studies (Ji et al., 2005; Xu et al., 2007; Liu et al., 2013; Kołaczek et al., 2014). In previous studies, TOC contents in surface sediments have been interpreted mainly to reflect climate factors that influence terrestrial plant growth or the input processes of terrestrial organic matter to lakes and rivers (Ji et al., 2005; Xu et al., 2007; Kołaczek et al., 2014). However, the environmental significance of the TOC content may vary in different study areas. Xu et al. (2006) suggested that high values of TOC in the Qinghai Lake sediments were indicative of high precipitation. Hartmann and Wünnemann (2009) reported that the TOC contents in sediments from the Juyanze paleolake were influenced by lake salinity and runoff. Moreover, TOC contents were interpreted as proxies for effective humidity (An et al., 1993; Long et al., 2010; Wang et al., 2013; Li et al., 2016b). Furthermore, some non-climate factors can also affect the TOC content (Sifeddine et al., 2011; Woszczyk et al., 2011). Hence, understanding the environmental significance of the TOC in arid regions is crucial in order to evaluate the reliability of paleoenvironmental reconstructions.

The Badain Jaran Desert is located in a hyper-arid region of northwestern China. It is a key region for understanding past climatic change and environmental evolution studies because it is located in the transition zone between the Asian summer monsoon and the westerly winds in China (Wang et al., 2005; Yang et al., 2011; Li et al., 2015). Thus, it is an ideal region for studying changes in climate at different time scales (Yang and Scuderi, 2010; Li et al., 2016c; Wang et al., 2016). However, for lakes in the hinterland of deserts, which are not recharged by river runoff, sediment is only transported by the wind (Li et al., 2018). Thus, allochthonous organic matter $(\mathrm{OM})$ transport and deposition processes differ from those in lakes with river discharge. Moreover, OM content is lower in hinterland desert lakes than other regions, and surface sediments do not receive a substantial terrigenous OM contribution. Slight changes in the TOC 
content could be caused by numerous factors including climate and non-climate factors. Therefore, the TOC spatial distribution of the lake sediments and their environmental significance remains unclear. Moreover, it is still uncertain whether the TOC content can be used as a proxy for paleoenvironmental studies in this area.

In this study, five lakes in the hinterland of the Badain Jaran Desert without runoff recharge were selected, and a total of 109 lake surface samples collected from the five lakes were used to analyze the spatial distribution of surface-sediment TOC and $\mathrm{C} / \mathrm{N}$ ratios. Moreover, we also evaluated the environmental significance of the sediment $\mathrm{TOC}$ and $\mathrm{C} / \mathrm{N}$ ratio records in the study area.

\section{Study site}

The Badain Jaran Desert $\left(39^{\circ} 04^{\prime} 15^{\prime \prime}-42^{\circ} 12^{\prime} 23^{\prime \prime} \mathrm{N}\right.$, $99^{\circ} 23^{\prime} 18^{\prime \prime}-104^{\circ} 34^{\prime} 02^{\prime \prime} \mathrm{E}$ ) is located in northwest China (Fig. 1a). With an area of approximately $52,100 \mathrm{~km}^{2}$, it is the second largest desert in China. The elevation of the area varies between $1,500 \mathrm{~m}$ above sea level in the southeast, and $900 \mathrm{~m}$ above sea level in the northwest. The desert is bordered to the south and east by the Beida-Shan and Yabulai-Shan mountain ranges, respectively (Fig. 1b).

The Badain Jaran Desert is located in the mid-latitude arid region (Zhu et al., 1980). The average annual temperature is approximately $8^{\circ} \mathrm{C}$, and the mean summer and winter temperatures are 25 and $-9^{\circ} \mathrm{C}$, respectively (Ma et al., 2014). The desert is strongly continental, and the an- nual average precipitation decreases gradually from 120 to $40 \mathrm{~mm}$ from the southeast to the northwest of the desert. Annual precipitation in the hinterland of the Badain Jaran Desert is $\sim 100 \mathrm{~mm}$ (Li et al., 2013; Ma et al. 2014). In contrast to the distribution of precipitation, evaporation increases gradually from the southeast to the northwest. Mean annual water surface evaporation is more than $1000 \mathrm{~mm}$ (Yang et al., 2010; Li et al., 2016a).

In the southeast of the Badain Jaran Desert, sand hills have average heights between $200-300 \mathrm{~m}$, and reach as high as $460 \mathrm{~m}$. A total of 110 lakes are found in this region (Wang et al., 2016), most of which are saline soda lakes with high Total Dissolved Solids (TDS). The lakes are recharged by groundwater, not surface runoff, and due to the extremely low precipitation and high potential evaporation rates (Ma et al., 2014), the lakes have variable concentrations of TDS (Wu et al., 2014; Dong et al., 2016). However, attributed to groundwater reductions in the drainage areas, the number of lakes in the region had fallen to 68 in 2006 (Zhang et al., 2013). Most plants that grow in the region around the lakes, are hygrophytes and halophytes, which are distributed concentrically around the lakes (Fig. 2).

Five lakes in the hinterland of the Badain Jaran Desert of varying area dimensions and TDS concentrations were selected (Fig. 1c). The general characteristics of the lakes are listed in Tab. 1, and include the locations, lake areas dimensions, and the TDS concentrations.
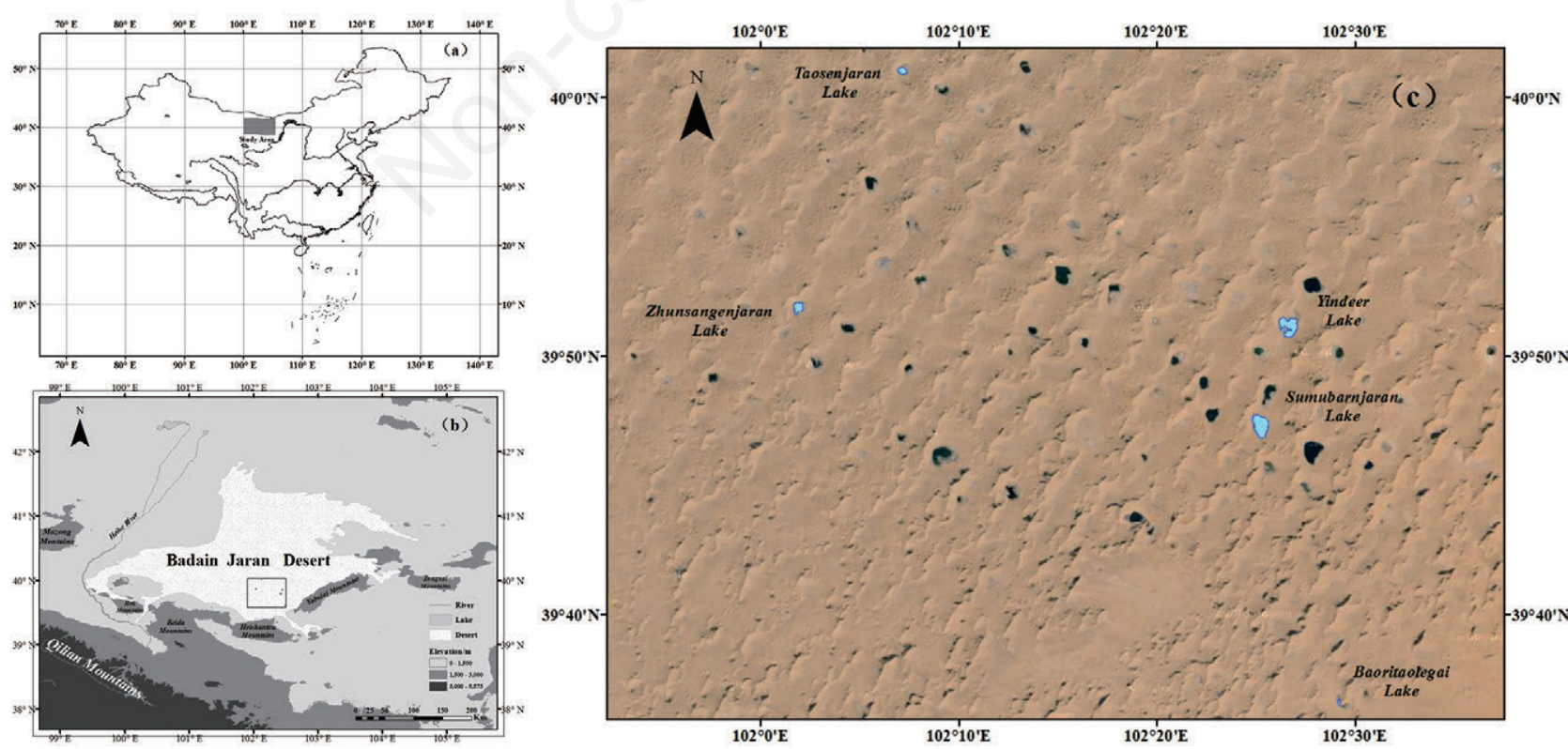

Fig. 1. a) Location of the study area. b) Location of the sampled lakes in the hinterland of Badain Jaran Desert. c) Distribution of the sampling lakes. 


\section{METHODS}

\section{Surface sediment sampling}

In May 2015, 109 surface sediment samples were collected from five lakes in the hinterland of the Badain Jaran Desert. Of these, 22 samples were collected from Sumubarunjaran Lake (Fig. 3a), 25 samples from Zhunsangenjaran Lake (Fig. 3b), 23 samples from Taosenjaran Lake (Fig. 3c), 25 samples from Yindeer Lake (Fig. 3c), and 14 samples were collected from Baoritaolegai Lake (Fig. 3e). The distribution of the sampling points in the lakes was es- tablished based on latitude and longitude, and the exact geographical positions of the sampling points were tracked using Global Positioning System (GPS). Fig. 3 shows the distribution of the specific sampling points.

\section{Methods}

All samples were air-dried naturally and ground to pass through a size 100 mesh. Samples of approximately $0.5 \mathrm{~g}$ each were weighed, and the measured values, accurate to $0.0001 \mathrm{~g}$, were recorded. Each sample was then placed in a centrifuge tube with $10 \mathrm{~mL}$ of $10 \mathrm{~mol} \mathrm{~L}^{-1} \mathrm{HCl}$ to remove carbonates and was left to stand for $24 \mathrm{~h}$ to en-

Tab. 1. Basic characteristics of five sampled lakes in this study.

\begin{tabular}{lccc} 
Lake & \multicolumn{1}{c}{ Location } & \multicolumn{1}{c}{ Area $\left(\mathrm{km} \mathrm{m}^{2}\right)$} \\
Sumubarunjaran & $39^{\circ} 46^{\prime} 52^{\prime \prime}-39^{\circ} 47^{\prime} 46^{\prime \prime} \mathrm{N}, 102^{\circ} 24^{\prime} 47^{\prime \prime}-102^{\circ} 25^{\prime} 34^{\prime \prime} \mathrm{E}$ & 1.27 & 59.50 \\
\hline Yindeer & $39^{\circ} 50^{\prime} 46^{\prime \prime}-39^{\circ} 51^{\prime} 32^{\prime \prime} \mathrm{N}, 102^{\circ} 26^{\prime} 06^{\prime \prime}-102^{\circ} 27^{\prime} 04^{\prime \prime} \mathrm{E}$ & 1.1 & 0.39 \\
\hline Zhunsangenjaran & $39^{\circ} 51^{\prime} 36^{\prime \prime}-39^{\circ} 52^{\prime} 05^{\prime \prime} \mathrm{N}, 102^{\circ} 01^{\prime} 37^{\prime \prime}-102^{\circ} 02^{\prime} 06^{\prime \prime} \mathrm{E}$ & 173.29 \\
\hline Taosenjaran & $40^{\circ} 00^{\prime} 54^{\prime \prime}-40^{\circ} 01^{\prime} 12^{\prime \prime} \mathrm{N}, 102^{\circ} 06^{\prime} 54^{\prime \prime}-102^{\circ} 07^{\prime} 19^{\prime \prime} \mathrm{E}$ & 158.00 \\
\hline Baoritaolegai & $39^{\circ} 36^{\prime} 25^{\prime \prime}-39^{\circ} 36^{\prime} 43^{\prime \prime} \mathrm{N}, 102^{\circ} 57^{\prime} 22^{\prime \prime}-101^{\circ} 57^{\prime} 47^{\prime \prime} \mathrm{E}$ & 0.07 & 1.15
\end{tabular}

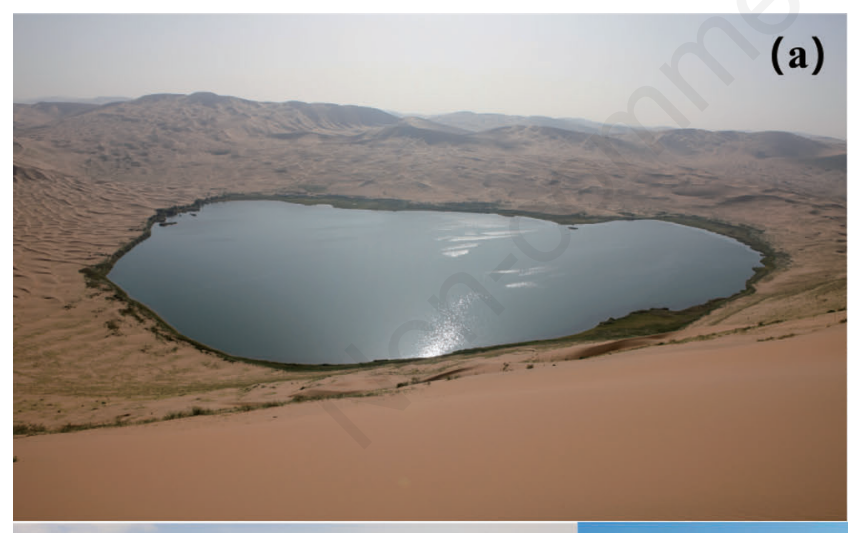

(c)

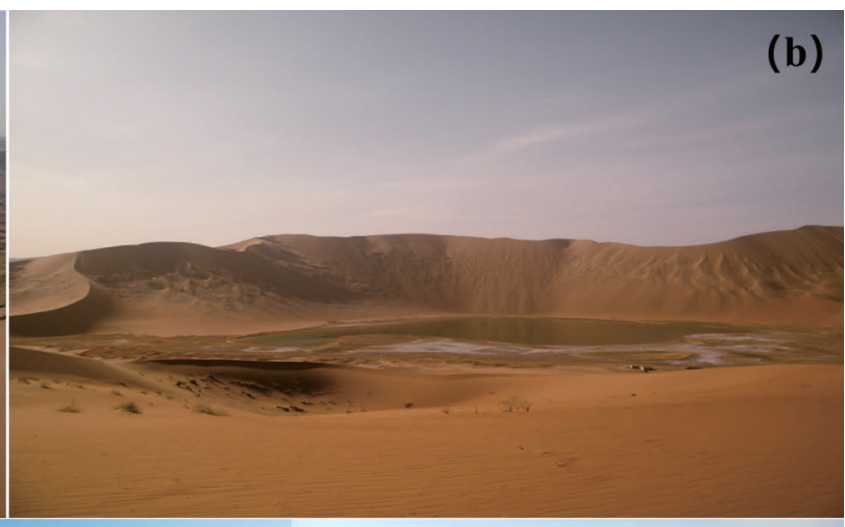

(d)

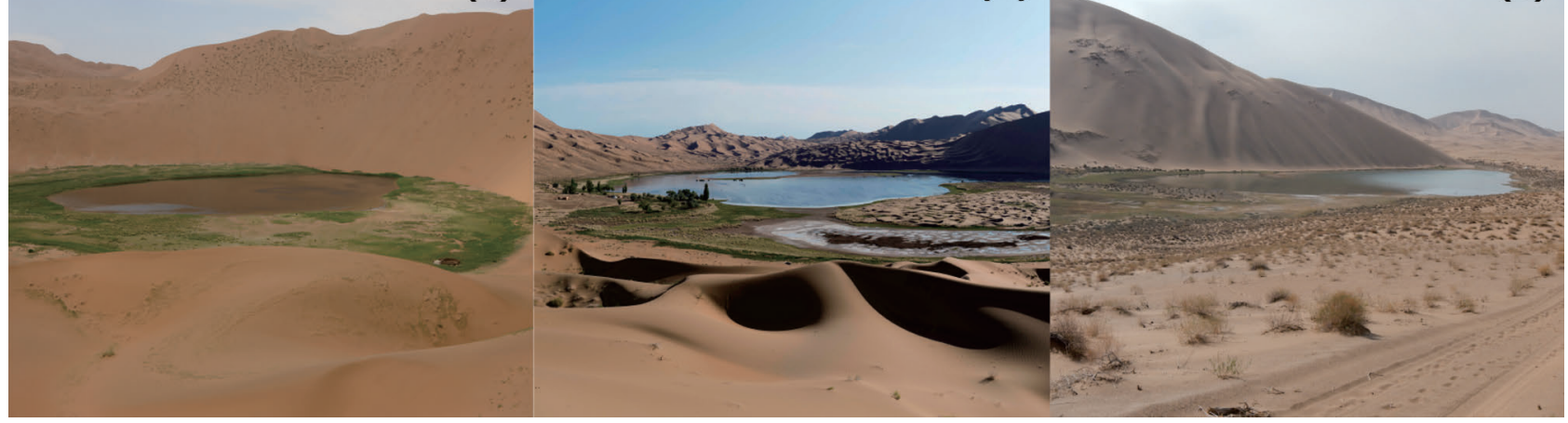

Fig. 2. Imagine of sampled lakes. a) Sumubarunjaran Lake; b) Zhunsangenjilin Lake; c) Taosenjilin Lake; d) Yindeer Lake; e) Baoritaolegai Lake. 
sure complete removal. Subsequently, the $\mathrm{pH}$ of each sample was brought to neutral using $5 \mathrm{~mL}$ of deionized water and centrifuged 4-5 times. Samples were then dried in a drum wind drying oven and placed in a room-temperature environment for $2 \mathrm{~h}$ to attain moisture absorption equilibrium with the air. Finally, the samples were weighed, and the values accurate to $0.0001 \mathrm{~g}$, were recorded. TOC and Total $\mathrm{N}$ contents of each treated sample were measured using a Vario-III element analyzer (Elementar Analysensysteme $\mathrm{GmbH}$, Germany), the estimated error was $<0.001 \%$. To calculate the actual organic carbon and nitrogen contents of the untreated, dry sediment samples, the following formula was applied:

$$
M_{0}=M^{*} G / G_{0}
$$

Where $M_{0}$ is percentage of the element in the actual sample (\%), $M$ is the percentage of the element in the treated sample (\%), $G_{0}$ is the actual sample weight $(\mathrm{g})$, and $G$ is the treated sample weight $(\mathrm{g})$.

The spatial distributions of the TOC contents and $\mathrm{C} / \mathrm{N}$ ratio in the surface sediments were analyzed using Topo to Raster in ArcGIS 10.2.

\section{RESULTS}

\section{Contents of TOC and $\mathrm{C} / \mathrm{N}$}

The TOC contents of the surface sediments from the five sampled lakes ranged from $0.03 \%$ to $1.01 \%$ (Tab. 2), the maximum mean value of $0.41 \%$ was from Baoritaolegai Lake, and the minimum mean value of $0.19 \%$ was from Taosenjaran Lake (Tab. 2). Moreover, Tab. 2 yields $\mathrm{C} / \mathrm{N}$ ratios from 3.77 to 18.75 , and each lake included sampling sites in which the $\mathrm{C} / \mathrm{N}$ ratio was larger than 10 , however, the $\mathrm{C} / \mathrm{N}$ of most sampling sites less than 10 .

\section{Spatial distribution of TOC and C/N}

Fig. 4 shows that there are distinct spatial distribution

Tab. 2. Total organic carbon concentrations and $\mathrm{C} / \mathrm{N}$ ratios in the surface sediments of five lakes.

\begin{tabular}{lcr} 
Lake & Range and mean of TOC concentrations $(\%)$ & \multicolumn{1}{c}{ Range and mean of C/N ratio (\%) } \\
Sumubarunjaran & $0.13-0.8,0.34$ & $4.73-12.4,8.51$ \\
\hline Yindeer & $0.15-0.88,0.37$ & $4.04-13.49,10.62$ \\
\hline Zhunsangenjaran & $0.11-0.62,0.30$ & $4.94-13.77,8.40$ \\
\hline Taosenjaran & $0.03-1.01,0.19$ & $5.47-18.75,7.45$ \\
\hline Baoritaolegai & $0.10-0.76,0.41$ & $3.77-11.69,9.27$
\end{tabular}

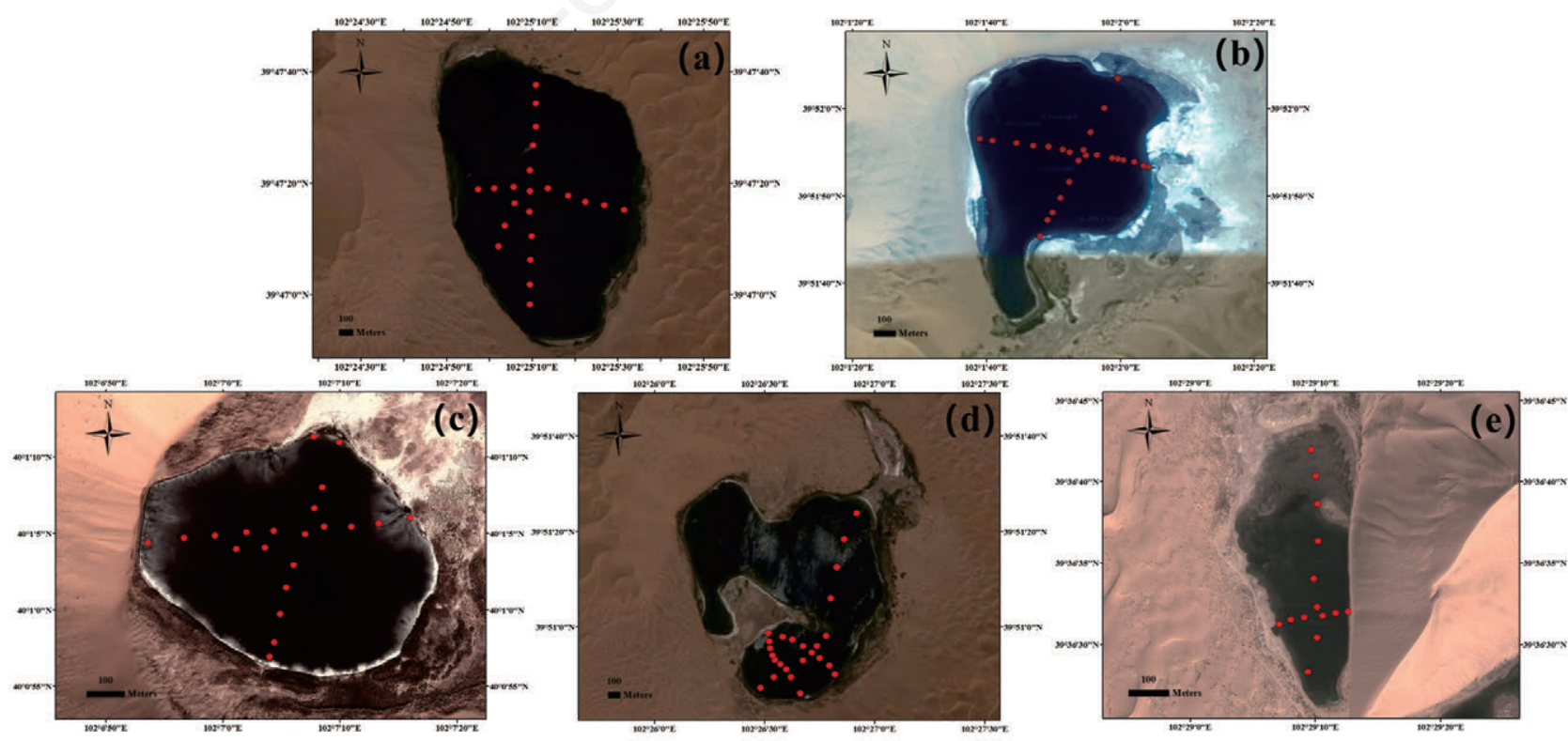

Fig. 3. Sampled lakes and their sampling point distribution in the hinterland of the Badain Jaran Desert. a) Sumubarunjaran Lake, b) Zhunsangenjilin Lake, c) Taosenjilin Lake, d) Yindeer Lake, e) Baoritaolegai Lake. 
characteristics for the TOC and $\mathrm{C} / \mathrm{N}$ ratios in the lake surface sediments. There are, however, differences in the variation of the TOC contents in the lakes and in the corresponding spatial relationships between the TOC and the $\mathrm{C} / \mathrm{N}$ ratios. There were multiple sites with relatively high values of TOC contents and $\mathrm{C} / \mathrm{N}$ ratios in Taosenjaran Lake, Zhunsangenjaran Lake, Sumubarunjaran Lake, and Yindeer Lake, and the highest values of the TOC contents were located roughly in the centers of these lakes (Fig. 4 $\left.\mathrm{a}_{1}-\mathrm{d}_{1}\right)$. The TOC contents and $\mathrm{C} / \mathrm{N}$ ratios showed similar spatial characteristics for the concentric distribution. Higher values in were found the deeper areas rather than in the shallow areas (Fig. 4 a-d).

In contrast, the TOC contents of surface sediments from Baoritaolegai Lake varied across the different regions of the lake (Fig. $4 \mathrm{e}_{1}$ ). The distribution of the TOC contents in the surface sediments of the lake showed a decreasing trend from west to east. The TOC content in sediments from the southern part of the lake showed a relatively high value at one site, with surrounding samples displaying lower values. The $\mathrm{C} / \mathrm{N}$ ratio values of the lake sediments decreased from the east to the west side of the lake, and this did not correlate with the spatial pattern of the TOC content (Fig. 4e).

\section{DISCUSSION}

\section{Source of organic matter}

$\mathrm{C} / \mathrm{N}$ ratios can be used to evaluate the predominance of autochthonous versus allochthonous sources of OM (Meyers and Ishiwatari, 1993). When sediment OM in lakes originates primarily from autochthonous materials, the $\mathrm{C} / \mathrm{N}$ ratio is between 4 and 10 , indicating an input of protein-rich and cellulose-poor aquatic organisms (Krishnamurthy et al., 1986; Meyers, 2003). When OM originates from allochthonous material, the $\mathrm{C} / \mathrm{N}$ ratio is typically greater than 20 due to the protein-poor and cellulose-rich nature of terrestrial plants (Meyers, 1994). In this study, there were sampling sites with surface sediment $\mathrm{C} / \mathrm{N}$ ratios greater than 10 in each of the sampled lakes (Tab. 2). These results indicate that a portion of the $\mathrm{OM}$ in these surface sediments originated from allochthonous materials. Moreover, the $\mathrm{C} / \mathrm{N}$ ratio of most of the surface sediment samples were lower than 10 (Tab. 2), and it can be inferred that the OM at most of these sites is autochthonous. Therefore, in this study, the OM in the surface sediments included both allochthonous and autochthonous materials. For lakes in the hinterland of the Badain Jaran

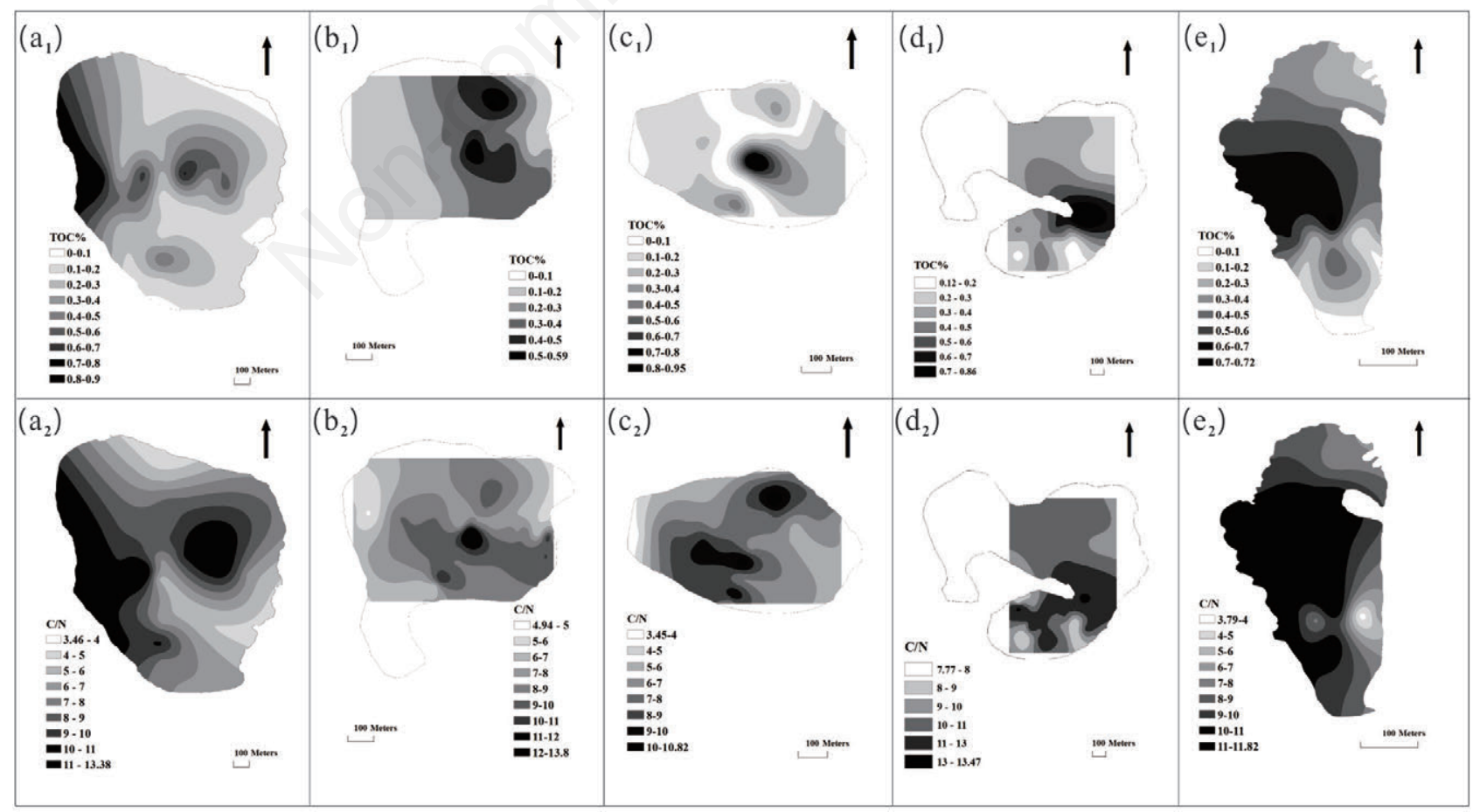

Fig. 4. Spatial distributions of TOC and C/N in the surface sediments of the sampled lakes. $a_{1}, a_{2}$ ) Sumubarunjaran Lake; $b_{1}$, $b_{2}$ ) Zhunsangenjaran Lake; $\mathrm{c}_{1}, \mathrm{c}_{2}$ ) Taosenjaran Lake; $\mathrm{d}_{1}, \mathrm{~d}_{2}$ ) Yindeer Lake; $\mathrm{e}_{1}, \mathrm{e}_{2}$ ) Baoritaolegai Lake. 
Desert, which are not recharged by river runoff, sediment is only transported by the wind. Thus, the allochthonous OM found in the lakes of this study were transported to the lakes by wind.

\section{The spatial distributions and influencing factors of TOC contents and $\mathrm{C} / \mathrm{N}$}

Fig. 4 shows that the higher TOC contents were located roughly in the middle of four of the lakes (Fig. 4 $\left.a_{1}-d_{1}\right)$. Additionally, spatial distributions of the TOC contents showed similar concentric circles in the lakes with high values at the center (Fig. $4 a_{1}-d_{1}$ ). Thus, the TOC values were higher in the deeper areas rather than in the shallow areas, which indicates accumulation of organic matter in the deep-water sedimentary center of the lakes (Kastner et al., 2010). The spatial distribution of the $\mathrm{C} / \mathrm{N}$ ratios showed similar concentric circles with higher values in the deeper areas rather than in the shallow areas (Fig. 4 $a_{2}-d_{2}$ ). All of the high values were greater than 10 . Moreover, the spatial distributions of sites with relatively high TOC contents and $\mathrm{C} / \mathrm{N}$ ratios were generally similar, which indicates that the TOC content of the surface sediments was notably influenced by allochthonous OM.

OM transported from catchment to the lake is influenced by a number of factors, including river input, underwater topography, wind, and wind-induced lake waves, which lead to different eventual patterns of spatial distribution (Shen et al., 2011). For lakes in desert hinterlands that are not recharged by river runoff, sediment input to the lake comes from wind transport alone. However, under the influence of wind-induced currents and waves, OM transported into the lake can be resuspended and redistributed (Kelderman et al., 2012). At different water depths, lake waves can create varying amounts of disturbance on the lake bottom. Near the shore, waves are relatively strong, and organic matter deposited at the bottom of the lake is more susceptible to resuspension. However, lake waves in deep-water areas have a weaker influence and lower capacity for causing resuspension; therefore, deepwater areas of the lake serve as the "final sedimentation basins" for resuspended sedimentary material (Kelderman et al., 2012). Thus, OM in this study area was resuspended by lake waves during the deposition process, and was therefore also affected by underwater topography. These factors resulted in the enrichment of the OM in the deepwater areas of the lakes and a gradual decrease in the OM content from the deep-water area outward to the surrounding areas. Moreover, because the deep-water area is often a reducing environment, it is more conducive to the preservation of $\mathrm{OM}$, and therefore, as a consequence, includes relatively more OM. Furthermore, because the primary productivity of these lakes are low, the allochthonous OM is the main contributor to the relatively high values of TOC. Consequently, the spatial distributions of the TOC contents and the $\mathrm{C} / \mathrm{N}$ ratios are approximately consistent. However, compared to the other four sampled lakes discussed above, Baoritaolegai Lake has a smaller area $(0.07$ $\mathrm{km}^{2}$ ), is relatively shallow, and the spatial distribution of the TOC did not show notable enrichment (Fig. 4e $\mathrm{e}_{1}$ ). It has been shown that the spatial distribution of sediments in small lakes is typically dominated by a particular factor and that the resulting distribution is relatively simple (Sifeddine et al., 2011). The spatial distribution of TOC contents in the surface sediments of Baoritaolegai Lake differed from those of the other four lakes, and also varied between different regions of the lake. In particular, the TOC contents of the surface sediments gradually decreased from west to east in the northern part of the lake, but showed similar concentric circles with the highest contents in the center in the southern part of the lake. The reason for this phenomenon is that when a lake's area is smaller, more factors strongly influence the distribution of OM (Woszczyk et al., 2011), such as the decomposition of $\mathrm{OM}$ at shallow water depths and the redepositing of OM caused by the repeated disturbances of lake waves. Furthermore, Baoritaolegai Lake is a freshwater lake and has the highest productivity of the five lakes that were studied. The distribution of TOC in Baoritaolegai Lake is therefore likely to be less affected by allochthonous matter compared to the sampled lakes with lower productivity.

Based on the above analysis and a comparison of the spatial distributions of TOC contents and $\mathrm{C} / \mathrm{N}$ ratios in the five sampled lakes, it can be stated that the OM in the surface sediments of these lakes is restricted by a number of factors including underwater topography, wind, and windinduced lake waves. In this study, when the lake area was greater than $0.21 \mathrm{~km}^{2}$, and had a corresponding relatively deep lake bottom, OM in the surface sediments was notably enriched and showed a spatial distribution that correlated to changes in the water depth.

\section{Environmental implications}

TOC has been used to represent the abundance of organic matter in sediments (Tian et al., 2013), high values of TOC indicate a high level of primary productivity (Kołaczek et al., 2014) and conditions suitable for the preservation of OM . In arid regions, previous studies suggested that biomass productivity was controlled by the effective precipitation (An et al., 1993). Thus, TOC content in lake sediments has been interpreted as a proxy index for effective precipitation in arid regions (Li et al., 2009; An et al., 2012; Wang et al., 2013; Li et al., 2016b).

However, in desert hinterlands, TOC content in the sediments is extremely low. In the Kubuqi Desert of north China, the TOC content is less than 1\% (Yang et al., 2016). In the Tengger Desert of northwest China, the TOC content from the terminal lake sediments is only between $0.06 \%$ and 2.23\% (Li et al., 2009). Moreover, in the Juyanze pa- 
leolake, a terminal lake at the northwest margin of the Badain Jaran Desert, the TOC content was reported to be less than 2\% during the Holocene (Hartmann and Wünnemann, 2009). In this study, the TOC content was extremely low $(0.03 \%-1.01 \%)$, the maximum average TOC content from all five sampled lakes however was $0.41 \%$ in Baoritaolegai Lake, reflecting the much lower sedimentary OM content in the hinterland of the Badain Jaran Desert. Therefore, changes in the low TOC content were easily influenced by both climatic and non-climatic factors.

Our results revealed that the spatial distribution of the TOC contents in the surface sediments of lakes in the Badain Jaran Desert hinterlands were affected by the underwater topography and the hydrodynamic forces of the lakes. Therefore, with lake areas changing over the course of lake evolution, the spatial distribution of the TOC content in the lake sediments would vary, which would affect how information pertaining to climate change associated with the TOC contained in the sediments would be preserved. Changes in lake area during lake evolution, which cause different patterns in the deposition of OM in different areas of a lake, were not taken into account. A decrease in the effective humidity would cause a decrease in the lake's water level, with intensified disturbance from lake waves and enrichment in TOC in the deep-water area, which would correspond to an increase in the TOC content. Therefore, TOC content can be affected by many factors and cannot be used as a single index to reconstruct paleoclimatic changes. Furthermore, because organic geochemical indices are multi-solution and influenced by many environmental factors, it remains necessary to combine multiple indicators to reconstruct the paleoenvironments of lakes and their basins based on the TOC contents of surface sediments in lakes.

\section{CONCLUSIONS}

For lakes in the hinterland of the Badain Jaran Desert without runoff recharge, surface-sediment $\mathrm{OM}$ in the lake are extremely low and consisted of both allochthonous $\mathrm{OM}$ carried by wind and autochthonous OM from the lakes, but the low $\mathrm{C} / \mathrm{N}$ ratios indicated the sources to be mostly autochthonous.

The TOC contents and $\mathrm{C} / \mathrm{N}$ ratios of the surface sediments in these lakes had clear spatial distributions because the OM content was affected by underwater topography and enriched by the action of wind-induced lake wave disturbances in larger lakes $\left(>0.21 \mathrm{~km}^{2}\right)$. However, in small lakes, the OM was affected by many factors, and the spatial distributions of the TOC contents and $\mathrm{C} / \mathrm{N}$ ratios did not reveal clear correlations.

The spatial distribution of the TOC contents in surface sediments of the sampled lakes was affected by lake area. With decreasing lake area, organic matter accumulated more in deeper waters. However, the spatial distribution of the TOC content challenges the interpretation of this index for use in paleoclimate and paleoenvironmental reconstructions. Therefore, the effects of changes in lake area must be considered when reconstructing paleolake evolution based on the TOC contents of lake sediments. Furthermore, the OM content of lake surface sediments is extremely low in arid areas, and the OM itself may have multiple sources and be affected by multiple processes, thus, a single proxy (TOC content) cannot be used to reconstruct the evolution of the lakes.

\section{ACKNOWLEDGMENTS}

The authors thank the editors and the anonymous reviewers for their constructive comments, which led to the significant improvement of this manuscript. Moreover, the authors are grateful for the able assistance of Fangli Wei, Meng Li and Qiang Ren during field work. Prof. Nai'ang Wang and Dr. Liqiang Zhao provide the imagine of sampled lakes (Fig. 2). This work was supported by the National Natural Science Foundation of China (No. 41530745 and 41771211) and the Fundamental Research Funds for the Central Universities (lzujbky-2017-215 and lzujbky-2017-it104).

\section{REFERENCES}

An Z, Colman SM, Zhou W, Li X, Brown ET, Jull AJT, Cai Y, Huang Y, Lu X, Chang H, 2012. Interplay between the Westerlies and Asian monsoon recorded in Lake Qinghai sediments since $32 \mathrm{ka}$. Sci. Rep. 2:619.

An Z, Porter SC, Zhou W, Lu Y, Donahue DJ, Head M, Wu X, Ren J, Zheng H, 1993. Episode of strengthened summer monsoon climate of Younger Dryas age on the Loess Plateau of central China. Quat. Res. 39:45-54.

Chen F, Yu Z, Yang M, Ito E, Wang S, Madsen DB, Huang X, Zhao Y, Sato T, John B. Birks H, Boomer I, Chen J, An C, Wünnemann B, 2008. Holocene moisture evolution in arid central Asia and its out-of-phase relationship with Asian monsoon history. Quat. Sci. Rev. 27:351-364.

Dong C, Wang N, Chen J, Li Z, Chen H, Chen L, Ma N, 2016. New observational and experimental evidence for the recharge mechanism of the lake group in the Alxa Desert, north-central China. J. Arid Environ. 124:48-61.

Hartmann K, Wünnemann B, 2009. Hydrological changes and Holocene climate variations in NW China, inferred from lake sediments of Juyanze palaeolake by factor analyses. Quat. Int. 194:28-44.

Hobbs WO, Edlund MB, Umbanhowar CE, Camill P, Lynch JA, Geiss C, Stefanova V, 2017. Holocene evolution of lakes in the forest-tundra biome of northern Manitoba, Canada. Quat. Sci. Rev. 159:116-138.

Ji S, Xingqi L, Sumin W, Matsumoto R, 2005. Palaeoclimatic changes in the Qinghai Lake area during the last 18,000 years. Quat. Int. 136:131-140. 
Kastner S, Ohlendorf C, Haberzettl T, Lücke A, Mayr C, Maidana NI, Schäbitz F, Zolitschka B, 2010. Southern hemispheric westerlies control the spatial distribution of modern sediments in Laguna Potrok Aike, Argentina. J. Paleolimnol. 44:887-902.

Kelderman P, Ang'weya RO, Rozari PD, Vijverberg T, 2012. Sediment characteristics and wind-induced sediment dynamics in shallow Lake Markermeer, the Netherlands. Aquatic Sci. 74:1-13.

Kołaczek P, Mirosław-Grabowska J, Karpińska-Kołaczek M, Stachowicz-Rybka R, 2014. Regional and local changes inferred from lacustrine organic matter deposited between the Late Glacial and mid-Holocene in the Skaliska Basin (northeastern Poland). Quat. Int. 45:544-544.

Krishnamurthy R, Bhattacharya SK, Kusumgar S, 1986. Palaeoclimatic changes deduced from ${ }^{13} \mathrm{C} /{ }^{12} \mathrm{C}$ and $\mathrm{C} / \mathrm{N}$ ratios of Karewa lake sediments, India. Nature 323:150-152.

Li Y, Wang N, Cheng H, Long H, Zhao Q, 2009. Holocene environmental change in the marginal area of the Asian monsoon: a record from Zhuye Lake, NW China. Boreas 38:349-361.

Li Z, Pan N, He Y, Zhang Q, 2016a. Evaluating the best evaporation estimate model for free water surface evaporation in hyper-arid regions: a case study in the Ejina basin, northwest China. Environ Earth Sci 75:295.

Li Z, Wang N, Cheng H, Li Y, 2016b. Early-middle Holocene hydroclimate changes in the Asian monsoon margin of northwest China inferred from Huahai terminal lake records. J. Paleolimnol. 55:289-302.

Li Z, Wang N, Li R, Ning K, Cheng H, Zhao L, 2015. Indication of millennial-scale moisture changes by the temporal distribution of Holocene calcareous root tubes in the deserts of the Alashan Plateau, Northwest China. Palaeogeogr. Palaeoclimatol. Palaeoecol. 440:496-505.

Li Z, Wang N, Li Y, Zhang Z, Li M, Dong C, Huang R, 2013. Runoff simulations using water and energy balance equations in the lower reaches of the Heihe River, northwest China. Environ Earth Sci 70:1-12.

Li Z, Wang N, Zhang X, Cheng H, Li Y, 2016c. High precipitation and low evaporation resulted in high lake levels of the Juyanze paleolake, northwest China, during 34-26 cal kyr BP. Clim. Res. 69:193-207.

Li Z, Wei Z, Dong S, Chen Q, 2018. The paleoenvironmental significance of spatial distributions of grain size in groundwater-recharged lakes: A case study in the hinterland of the Badain Jaran Desert, northwest China. Earth Surf. Process. Landforms 43:363-372.

Liu C, Zhang J-F, Jiao P, Mischke S, 2016. The Holocene history of Lop Nur and its palaeoclimate implications. Quat. Sci. Rev. 148:163-175.

Liu W, Li X, An Z, Xu L, Zhang Q, 2013. Total organic carbon isotopes: A novel proxy of lake level from Lake Qinghai in the Qinghai -Tibet Plateau, China. Chem. Geol. 347:153-160.

Long H, Lai Z, Wang N, Li Y, 2010. Holocene climate variations from Zhuyeze terminal lake records in East Asian monsoon margin in arid northern China. Quat. Res. 74:46-56.

Ma N, Wang N, Zhao L, Zhang Z, Dong C, Shen S, 2014. Observation of mega-dune evaporation after various rain events in the hinterland of Badain Jaran Desert, China. Chin. Sci. Bull. 59:162-170.
Mackay AW, Bezrukova EV, Leng MJ, Meaney M, Nunes A, Piotrowska N, Self A, Shchetnikov A, Shilland E, Tarasov P, Wang L, White D, 2012. Aquatic ecosystem responses to Holocene climate change and biome development in boreal, central Asia. Quat. Sci. Rev. 41:119-131.

Members C, 1988. Climatic changes of the last 18,000 years: observations and model simulations. Science 241:1043-1052.

Meyers PA, 1994. Preservation of elemental and isotopic source identification of sedimentary organic matter. Chem. Geol. 144:289-302.

Meyers PA, 2003. Applications of organic geochemistry to paleolimnological reconstructions: a summary of examples from the Laurentian Great Lakes. Org. Geochem. 34:261-289.

Meyers PA, Ishiwatari R, 1993. Lacustrine organic geochemistry - an overview of indicators of organic matter sources and diagenesis in lake sediments. Org. Geochem. 20:867-900.

Shen J, Yuan H, Liu E, Wang J, Wang Y, 2011. Spatial distribution and stratigraphic characteristics of surface sediments in Taihu Lake, China. Chin. Sci. Bull. 56:179-187.

Sifeddine A, Meyers PA, Cordeiro RC, Albuquerque ALS, Bernardes M, Turcq B, Abrão JJ, 2011. Delivery and deposition of organic matter in surface sediments of Lagoa do Caçó (Brazil). J. Paleolimnol. 45:385-396.

Tian F, Herzschuh U, Dallmeyer A, Xu Q, Mischke S, Biskaborn BK, 2013. Environmental variability in the monsoon-westerlies transition zone during the last 1200 years: lake sediment analyses from central Mongolia and supra-regional synthesis. Quat. Sci. Rev. 73:31-47.

Wang N, Li Z, Li Y, Cheng H, 2013. Millennial-scale environmental changes in the Asian monsoon margin during the Holocene, implicated by the lake evolution of Huahai Lake in the Hexi Corridor of northwest China. Quat. Int. 313:100-109.

Wang N, Ning K, Li Z, Wang Y, Jia P, Ma L, 2016. Holocene high lake-levels and pan-lake period on Badain Jaran Desert. Sci. China Earth Sci. 59:1633-1641.

Wang Y, Cheng H, Edwards RL, He Y, Kong X, An Z, Wu J, Kelly MJ, Dykoski CA, Li X, 2005. The Holocene Asian monsoon: links to solar changes and North Atlantic climate. Science 308:854-857.

Woszczyk M, Bechtel A, Gratzer R, Kotarba MJ, Kokociński M, Fiebig J, Cieśliński R, 2011. Composition and origin of organic matter in surface sediments of Lake Sarbsko: A highly eutrophic and shallow coastal lake (northern Poland). Org. Geochem. 42:1025-1038.

Wu Y, Wang N, Zhao L, Zhang Z, Chen L, Lu Y, Lü X, Chang J, 2014. Hydrochemical characteristics and recharge sources of Lake Nuoertu in the Badain Jaran Desert. Chin. Sci. Bull. 59:886-895.

Xu H, Ai L, Tan L, An Z, 2006. Stable isotopes in bulk carbonates and organic matter in recent sediments of Lake Qinghai and their climatic implications. Chem. Geol. 235:262-275.

Xu H, Hou ZH, Ai L, Tan LC, 2007. Precipitation at Lake Qinghai, NE Qinghai-Tibet Plateau, and its relation to Asian summer monsoons on decadal/interdecadal scales during the past 500 years. Palaeogeogr. Palaeoclimatol. Palaeoecol. 254:541-549.

Yang X, Forman S, Hu F, Zhang D, Liu Z, Li H, 2016. Initial insights into the age and origin of the Kubuqi sand sea of northern China. Geomorphology 259:30-39.

Yang X, Ma N, Dong J, Zhu B, Xu B, Ma Z, Liu J, 2010. 
Recharge to the inter-dune lakes and Holocene climatic changes in the Badain Jaran Desert, western China. Quat. Res. 73:10-19.

Yang X, Scuderi L, Paillou P, Liu Z, Li H, Ren X, 2011. Quaternary environmental changes in the drylands of China - A critical review. Quat. Sci. Rev. 30:3219-3233.

Yang X, Scuderi LA, 2010. Hydrological and climatic changes in deserts of China since the late Pleistocene. Quat. Res. 73:1-9.

Zhang H, Chang F, Chen G, Zhen Q, Cai Y, Li H, 2013. Human impact on climate and eco-hydrological systems in the Badain Jaran desert in northwest China. E3 J. Environ. Res. Man. 4:310-317.

Zhang HC, Peng JL, Ma YZ, Chen GJ, Feng ZD, Li B, Fan HF, Chang FQ, Lei GL, Wünnemann B, 2004. Late Quaternary palaeolake levels in Tengger Desert, NW China. Palaeogeogr. Palaeoclimatol. Palaeoecol. 211:45-58.

Zhu Z, Wu Z, Liu S, 1980. [An outline of Chinese Desert].[Book in Chinese]. Science Press. 